\title{
“The Listening Posts are Certainly our Night Lights": Canadian Trench Newspapers During the Great War
}

\author{
Eric Story*
}

\begin{abstract}
Living in the trenches during the First World War, Canadian soldiers experienced extreme levels of stress. There were unending days of monotony, mud craters filled with water, and food tins stuffed with all-too-familiar consumable goods. Soldiers responded to this seemingly unbearable environment by adopting a number of practices that helped ease the stresses of daily life. One of these practices was the publication of their very own newspapers. 'Trench newspapers' featured stories, poems and cartoons, laden with humour, irony and sarcasm. For its part, the $7^{\text {th }}$ Battalion of the Canadian Expeditionary Force published its own newspaper called The Listening Post. This essay examines the eighth edition of The Listening Post, published in November 1915, to shed light upon soldier culture during the Great War. The essay reveals that trench newspapers provided soldiers with an invaluable means of dealing with life in the trenches.
\end{abstract}

Keywords: First World War, trench newspapers, soldier culture, Canadian Expeditionary Force, humour, trenches

The memory of the Great War has been drudged through the mud. Generals are labeled as mass murderers while soldiers, their obedient lambs, were sent out to the slaughter. Novels, memoirs, and films have contributed to this entrenched memory, which arose after the publication of All Quiet On The Western Front (1929), and remains in the public conscience to this day. ${ }^{1}$ This "stalemated" memory, as historian Tim Cook calls it, began to be challenged in the $1990 s$ with the introduction of cultural - or social - history. ${ }^{2}$ According to Jay Winter and Blaine Baggett, the ways in which soldiers made sense of the war form the life-blood of the cultural history of the Great War. ${ }^{3}$ As scholarly audiences became increasingly interested, social history

${ }^{2}$ Cook, 639.

${ }^{1}$ Tim Cook, Shock Troops: Canadian Fighting the Great War,

${ }^{3}$ Jay Winter and Blaine Baggett, The Great War and the 1917-1918, vol. 2 (Toronto: Penguin Group, 2008), 634637.

Shaping of the $20^{\text {th }}$ Century (London: Penguin Studio, 1996), 11.

*Department of History, College of Arts and Science, University of Saskatchewan, Saskatoon, SK, Canada

Correspondence: eric.story@usask.ca 
began to unpack this great myth that soldiers were their superiors' lackeys. The Great War was unquestionably horrendous, but the story of the rank and file soldier is not one of resignation; instead, the story is one of resilience.

For these soldiers, the smallest of comforts became tools of perseverance in the trenches of the Great War. Cigarettes, alcohol, daily rations of food, and humour became metaphorical shields, blunting the impact of the physically and psychologically draining life on the Western Front. Only recently and sparingly, however, have the scholars of the Great War turned their gaze to another tool: the trench newspapers that were published by and for the soldiers.

John Fuller's groundbreaking work on troop morale in British and Dominion armies paved the way for future scholars. In his first chapter, he examines 107 journals published by British and Dominion troops, and finds that a large function of these newspapers was to "amuse and entertain. ${ }^{\prime 4}$ Sometimes they attempted to increase morale; however, in all cases, these newspapers were representative of the lower-ranking soldier and came into being through individual initiative. ${ }^{5}$ Since Fuller, Stéphane Audoin-Rouzeau and Robert Nelson have also examined trench newspapers in national contexts. Audoin-Rouzeau, looking at French trench journalism, makes an insightful contention that these newspapers not only represented the attitudes in the trench, but the attitudes of the French nation as a whole. ${ }^{6}$ Instead of the nationalism that was present in French journalism, German journalism focused on fostering camaraderie among troops. Nelson's argues that German trench newspapers provided "ordinary soldiers" with masculine "justification[s] for the aggressive and occupational practices of the German army." ${ }^{\prime 7}$ Most recently, Graham Seal has conducted an exhaustive study

${ }^{4}$ J.G. Fuller, Troop Morale and Popular Culture in the British and Dominion Armies, 1914-1918 (Oxford: Clarendon

Press, 1991), 14-15, 20.

${ }^{5}$ Ibid, 20.

${ }^{6}$ Stéphane Audoin-Rouzeau, Men At War: National Sentiment and Trench Journalism in France During the First World War (Providence: Berg Publishers Limited, 1992), 155-184.

${ }^{7}$ Robert L. Nelson, German Soldier Newspapers of the First World War (Cambridge: Cambridge University Press, 2011), 1. on trench newspapers published by the allied nations, ${ }^{8}$ coming to similar conclusions as his predecessors. However, Seal finds that the trench press aided in the formation of a trench soldier identity. Furthermore, the trench press also allowed them to negotiate consent, thus giving them agency in the power struggle between them and their superiors. ${ }^{9}$

In the Canadian context, the historical literature is sparse. Beyond the metanarratives of Fuller and Seal, Tim Cook has briefly examined the Canadian trench press. Cook discerns that the newspapers allowed soldiers to express themselves in various manners, with the ultimate goal of making sense of the war. These newspapers were infused with humour and irony - a forum through which their grumblings could be voiced. ${ }^{10}$

This essay will examine one edition of the many trench newspapers that were published by Canadian troops. Although not all battalions published a newspaper, the 7 th Battalion's The Listening Post was one of the most widely read and circulated newspapers of the trench press. Selling 20,000 copies on the Western Front, ${ }^{11}$ its first edition was published in August 1915, and the last in 1919. In examining the eighth edition, which was published on November 25th 1915, four significant areas of the Canadian soldier experience will be highlighted. First, the broader war effort beyond the daily life of the Canadian trench soldier was trivialized, and for the most part, ignored. Second, soldiers frequently used humour and irony to normalize their experiences. Third, a divide existed between the home and war front so soldiers made a concerted effort to bridge that gap through the trench press. And fourth, in many cases, soldiers aired their grievances with sentiments of antiauthoritarianism and civilian disloyalty. All of these aspects demonstrate that The Listening Post served an essential purpose for these troops. The newspaper was a coping

${ }^{8}$ The allied nations included Britain, Canada, Australia, New Zealand and the United States, although Seal sometimes refers to both French and German newspapers.

${ }^{9}$ Graham Seal, preface to The Soldiers' Press: Trench Journals in the First World War (Basingstoke: Palgrave Macmillan, 2013), $x$.

${ }^{10}$ Cook, Shock Troops, 187-190.

${ }^{11}$ Fuller, 9. 
mechanism for those living in the unreal world of the trenches during the Great War, a lone light in an otherwise blackened night, and a warm belly of laughter in a cold, damp, muddy, wet, and bloody world.

A few columns of the eighth edition give the reader a glimpse of the wider war effort, although few stories are told from the battlefield. One such column, "Another breach of the Hague Convention," reported that Germans were using parasols and ostrich feathers to unfairly entice Canadian troops to expose themselves. ${ }^{12}$ Although the story is comical and far-fetched, the gas attack at the Second Battle of Ypres - an earlier breach of the Hague Convention - was not. In total, the 7th battalion lost 580 men. ${ }^{13}$ Stories such as this one are attempts to diffuse the horrors of modern warfare, and became an outlet to make light of particularly bloody moments.

Only in a few instances did the editors of the eighth edition tell the story of the larger war effort; even then, it was often told with a poem or joke. ${ }^{14}$ The editors and contributors were quite different from the "hyper-patriotic, soothsaying journalists" that historian Tim Cook describes as writing about the war from the comforts of their own homes and offices. ${ }^{15}$ Maclean's and Punch magazines were regularly circulated around the trenches, their writers often

${ }^{12}$ Early Canadiana Online, The Listening Post 8, November 25, 1915, 34, http://eco.canadiana.ca/view/oocihm.8_06774?page=1. From now on, it will be referred to as L.P.

${ }^{13}$ Tim Cook, At the Sharp End: Canadians Fighting the Great War, 1914-1916, vol. 1 (Toronto: Penguin Group, 2007), 65.

${ }^{14}$ In the column, "A Song Suggested for a certain R.O. to sing to Fritz," the use of poison gas is mentioned. It also makes reference to the "old dames and kids" who were killed during the Rape of Belgium in the early months of the war, and the sinking of various merchant ships by German U-Boats. See article in L.P., 33. The article following this one on the same page refers either to Lord Strathcona's Horse or the Canadian Cavalry Brigade at the Battle of Festubert in May 1915, and the dismounting of cavalry troops on 24 May. Both articles are written as poems with end rhymes. See Cook, At The Sharp End, 207217 for the Battle of Festubert.

${ }^{15}$ Cook, Shock Troops, 187. optimistically predicting that the war would end with the next big push. ${ }^{16}$ Through the pages of these magazines, soldiers perhaps heard too much about the larger war effort, and too little about what the rank-and-file trench soldier endured on a daily basis. Newspapers such as The Listening Post left the large-scale strategic appraisals to the mainstream press and instead provided their infantry readership with local - even tactical - jokes. It was conveyed in a language that all trench soldiers could understand.

The eighth edition also provides evidence of the disconnect between the home and war front. One contributor wrote about the inferior cigarettes that were being sent from home, and recommended that "smaller quantities and better qualities" be sent from "those at home who supply our soldiers with this very necessary article or comfort. ${ }^{\prime \prime 7}$ Little did loved ones at home realize that cigarettes provided temporary relief from the unwavering stench of urine, sweat, death, and burning ground..$^{18}$ Since soldiers lived in such horrid conditions, it seemed reasonable for them to ask that cigarettes be of the highest quality.

Although the eighth edition certainly demonstrates the divide between the home and war front, it also makes a concerted effort to bridge that gap. The second-page editorial addresses the lack of understanding military terminology by "our many civilian readers at home." The editorial then proceeds to define patrol, sentry and post. ${ }^{19}$ However, the language of the newspaper did not take on the rude or crude features that were commonplace in the Canadian army, thus hampering the process of closing that gap between civilian and soldier. ${ }^{20}$ Therefore, historians must be cautious when approaching trench newspapers, so as not to assume that they convey a complete picture of the trench experience.

Further evidence of the significant gap between the home and war front is illustrated in the debate over liquor

16 Ibid.

17 L.P., 30.

${ }^{18}$ Cook, At The Sharp End, 249.

19 L.P., 30.

${ }^{20}$ For the language of trench soldiers, see Cook, Shock Troops, 191. 
consumption. ${ }^{21}$ For many soldiers - as the eighth edition demonstrates - rum was a treat. In "Answers to Correspondents," the editor writes, "The most effective way to bring in the [Listening Post] is to make a noise like a rum issue.." ${ }^{22}$ In "The Battalion Rumourist's Calendar," arguably the most interesting and insightful column of this edition, are two references to rum, one of which states, "The Canteen doesn't pay." ${ }^{23}$ Obviously, this rumour was false. The canteen, of course, did pay, for as Tim Cook observes, rum "was an essential coping mechanism for the trench soldiers." ${ }^{24}$ In a trench advertisement, soldiers were told to use the "rum hair tonic" when getting a haircut from Kestinko, the Russian Barber of the 7 th Battalion. The rum had "splendid results when used externally" and "delightful results when used internally." ${ }^{25}$ However, a further look at the advertisement reveals something more: a private pays only one dollar, while a sergeant pays three. ${ }^{26}$

High-ranking officers often became the targets of vented frustrations in the eighth edition. In one of the opening columns entitled, "Mentioned in Despatches," the contributor, in words that dripped with sarcasm, congratulated Major-General Arthur Currie for his recent promotion to commander of the First Canadian Division in September 1915: "General Currie's promotion and honours are well deserved, won as they were on the field of battle [author's emphasis]." ${ }^{27}$ Located a few lines down,

21 This is the conclusion Tim Cook comes to in his article on wet canteens and the temperance movement during the Great War. Tim Cook, "Wet Canteens and Worry Mothers: Alcohol, Soldiers and Temperance Groups in the Great War," Histoire Social/Social History 35, no. 70 (2002): 330.

22 L.P., 34.

23 Ibid., 36.

${ }^{24}$ Cook, At The Sharp End, 244.

${ }^{25}$ L.P., 31.

26 Ibid.

${ }^{27}$ L.P., 29. Generals tended to be away from the front lines, often instructing and coordinating from the rear.
Lieutenant-Colonel Odlum, in a similar tone, was welcomed back from an "enforced" medical visit to England, "bucking medical boards" to get back to the front. ${ }^{28}$ This welcome illustrates a running joke among the lower-ranking soldiersthat an officer never refused his leave. ${ }^{29}$ To them, officers took every opportunity to avoid the dangers of the frontline. Taking leave was one of the ways, the rank-andfile soldier believed, they would be able to do so. Medical officers were also subjects of ridicule. In the first few pages of the eighth edition, acrostic poems mark the departure of the medical officer, Captain Gibson. One soldier gleefully wrote:

Gone has the Doc to a job on the staff

I am so glad I just sit here and laugh

Black was his look when he came on his round

Sour was his face when my mess tin he found

Onward and onward may he still go

Noting the flies while fighting the foe..$^{30}$

Certainly, this cheeky poem, along with the comments about Currie and Odlum, were expressions of the antiauthoritarianism theme running throughout this edition. ${ }^{31}$

Poems were also common features of the eighth edition. Almost every poem ends in rhyme and one can almost picture soldiers tapping their toes to the beat of a common tune, while reciting the words to these poems. In a way, the poems were much like songs, in that they brought men together through familiar words and verses. In fact, in the "Reports" column, the writer observed that poems were recited during a concert held by the 7 th and 1oth Battalions. $^{32}$ Therefore, not only songs but also poems helped "forge bonds of comradeship" and "endure the

28 Ibid.

${ }^{29}$ Tim Cook, "'I will meet the world with a smile and a joke': Canadian Soldiers' Humour in the Great War," Canadian Military History 22, no. 2 (2013), 57.

30 L.P., 32.

31 Tim Cook has examined Canadian soldiers' humour, and found that much of it had some form of antiauthoritarianism. Cook, “'smile and a joke,” 55.

${ }^{32}$ L.P., 35. 
strain of unending combat and service. ${ }^{1133}$ Poetry can thus be seen as an attempt to unite soldiers, and form a sort of trench soldier identity.

The final feature of the eighth edition of The Listening Post is the cartoons. The first is an ominous portrait of Prime Minister Robert Borden, promising to compensate the soldiers who have been injured in the line of duty. Keeping with the newspaper's sarcastic tone, Borden's eyes are darkened and shadowy, invoking a menacing presence. His arm is outstretched as if asking for money. ${ }^{34}$ The cartoon is a condemnation of returning veteran treatment, for the government had no infrastructure for compensating veterans until the summer of $1916 .{ }^{35}$ In effect, Borden and his government were taking lives away from families, without giving anything back for their sacrifice.

The second cartoon appears at the end, and returns to the comedic tone present throughout most of the newspaper. A "slacker," as the editors call him, pompously walks past the "Your King and Country Need You" sign. His coat and trousers, along with his walking cane, indicate that he is of the upper class, tying into the idea of the "conscription of wealth," which prominently featured in Canadian politics in later years. ${ }^{36}$ Furthermore, he is

33 This quote comes from Tim Cook, "The Singing War: Soldiers' Songs in the Great War," American Review of Canadian Studies 39, no. 3 (2009): 224. I argue--and which Cook does not--that poetry can also be a part of the larger lyrical environment that trench soldiers created.

${ }^{34}$ L.P., 30.

35 "Caring for Our Veterans: The History of the VAC," Clio's Current, February 10, 2014, http://clioscurrent.com/blog/2014/2/10/caring-for-ourveterans-the-history-of-vac. smoking a cigarette, undoubtedly a Woodbine, the most popular brand among the soldiers. ${ }^{37}$ The cartoon exemplifies a common pastime for trench soldiers: airing their grievances by targeting those who were "dodging their duties. ${ }^{138}$

"If the aeroplanes are our eyes by day, the listening posts are certainly our night lights, ${ }^{139}$ wrote the editor of the eighth edition. "Our paper has been named the 'Listening Post,' ever keen and alert to get all news that will, when presented to the soldier, carry his mind away from the nerve racking test of the firing line to the relaxation of fun and frolic. ${ }^{140}$ Newspapers, such as The Listening Post, were a "forum in which soldiers expressed themselves in a variety of ways. ${ }^{\prime \prime 1}$ In making light of the larger war effort, poking fun at commanding officers, or writing a rhyming verse or two, the eighth edition has shown that trench newspapers allowed soldiers to ground themselves in an inhospitable environment. Themes such as the gulf between the home and war front, anti-authoritarianism, and the value of camaraderie were packaged together using irony, humour and sarcasm. In hindsight, such themes cannot be mistaken, but we cannot be sure whether or not Canadian soldiers in the Great War thought of the trench newspapers in those terms. What is certain, however, is that the newspapers were something the soldiers could

36 "Conscription of wealth" is a complex term. According to David Tough, on the one hand, the wealthy were no different from the working class, and should be made available in order to prosecute the war effectively. On the other hand, it was a way to criticize the unequal burden sustained by the working class during the war, and as a way of punishing the rich who benefit from the war effort. David Tough, "'The rich ... should give to such an extent that it will hurt': 'Conscription of Wealth' and Political Modernism in the Parliamentary Debate on the 1917 Income War Tax," The Canadian Historical Review 93, no. 3 (2012): 387, 391.

${ }^{37}$ Cook, At The Sharp End, 249.

${ }^{38}$ Cook, "Smile and a joke," 51.

${ }^{39}$ L.P. 34.

${ }^{40}$ Ibid., 30.

${ }^{41}$ Cook, Shock Troops, 189. 
claim to be their own, something they controlled in an otherwise largely uncontrollable world. Through trench newspapers then, Canadian historians, following the scholarship of Tim Cook, can continue to explore the story of Canadian troops' perseverance. These stories provide the tools to break the deadlock that is the memory of Canada's Great War. 


\section{Bibliography}

Audoin-Rouzeau, Stéphane. Men At War, 1914-1918: National Sentiment and Trench Journalism in France During the First World War. Providence: Berg Publishers Limited, 1992.

"Caring for Our Veterans: The History of the VAC." Clio's Current, February 10, 2014. http://clioscurrent.com/blog/2014/2/10/caring-forour-veterans-the-history-of-vac.

Cook, Tim. At The Sharp End: Canadians Fighting the Great War, 1914-1916. Vol. 1. Toronto: Penguin Group, 2007.

--. "'I will meet the world with a smile and a joke': Canadian Soldiers' Humour in the Great War." Canadian Military History 22, no. 2 (2013): 48-62.

---. Shock Troops: Canadians Fighting the Great War, 19171918. Vol. 2. Toronto: Penguin Group, 2008.

---. "The Singing War: Soldiers' Songs in the Great War." American Review of Canadian Studies 39, no. 3 (2009): 224-241.

---. "Wet Canteens and Worrying Mothers: Alcohol, Soldiers and Temperance Groups in the Great War." Histoire Social/Social History 35, no. 70 (2002): 311-330.

Early Canadiana Online. The Listening Post 8. 25 November 1915, http://eco.canadiana.ca/view/oocihm.8_06774?pag $\mathrm{e}=1$.

Fuller, J.G. Troop Morale and Popular Culture in the British and Dominion Armies, 1914-1918. Oxford:

Clarendon Press, 1991.

Nelson, Robert L. German Soldier Newspapers of the First World War. Cambridge: Cambridge University Press, 2011.

Seal, Graham. The Soldiers'Press: Trench Journals in the First World War. Basingstoke: Palgrave Macmillan, 2013.

Tough, David. "'The rich . . should give to such an extent that it will hurt': 'Conscription of Wealth' and Political Modernism in the Parliamentary Debate on the 1917 Income War Tax." The Canadian Historical Review 93, no. 3 (2012): 382-407.
Winter, Jay, and Blaine Baggett. The Great War and the Shaping of the 2oth Century. London: Penguin Studio, 1996. 
Canadian Trench Newspapers During the Great War (Story)

University of Saskatchewan Undergraduate Research Journal 